\title{
䅺
}

\section{Homoseksualiteit en tydgerigtheid: 'n etiek van Bybellees?}

\author{
Gerrie Snyman \\ Departement Ou Testament \& Ou Nabye Oosterse Studies \\ Universiteit van Suid-Afrika \\ PRETORIA \\ E-pos: snymagf@unisa.ac.za
}

\begin{abstract}
Homosexuality and time-orientedness: an ethic of reading the Bible?

The article deals with the discourse on homosexuality within the Reformed Churches in South Africa. At stake is the exegete's subjectivity, or presupposed arbitrariness in the hermeneutical process. The author takes issue with the view that the Biblical text on homosexuality is a matter of principle and not a cultural prescription bounded by time. The author suggests that the current thinking on homosexuality is infused by a modern concept of heterosexuality and that the use of some Biblical texts that clearly prohibit sex between members of similar gender is problematic, because very little of the social structure that once supported these laws has been honoured since the late 20th century. Adding to the problem of the use of the Bible is intersexuality, which makes any clear principled distinction between two sexes difficult. The author concludes that the Bible readers' subjectivity (socio-political location) must be recognised and put on the table in order to indicate its role in the reading process.
\end{abstract}

\section{Opsomming}

Homoseksualiteit en tydgerigtheid: 'n etiek van Bybellees?

Hierdie artikel handel oor die diskoers met betrekking tot homoseksualiteit wat binne die Gerformeerde Kerke in SuidAfrika aan die gang is. Die eksegeet se subjektiwiteit, oftewel, die veronderstelde willekeurigheid in die hermeneutiese proses, word op die tafel geplaas. Die skrywer neem die siening dat die Bybelteks se uitspraak oor homoseksualiteit 'n beginselsaak is en nie 'n kulturele voorskrif wat tydgerig is nie, onder die loep. Hy suggereer dat die huidige denke oor homoseksualiteit 
beïnvloed is deur 'n moderne idee van heteroseksualiteit en dat die gebruik van sekere Bybeltekste wat seksuele verkeer tussen lede van dieselfde geslag verbied, problematies is omdat bitter min van die sosiale struktuur wat hierdie wette eens op 'n tyd ondersteun het, sedert die laat 20ste eeu uitgeleef word. Interseksualiteit, wat enige prinsipiële onderskeid tussen twee geslagte bemoeilik, vererger die probleem van Bybelgebruik. Die outeur kom tot die gevolgtrekking dat Bybellesers se subjektiwiteit (in terme van sosiopolitiese konteks) behoort erken en op die tafel geplaas te word ten einde die rol van subjektiwiteit in die leesproses aan te dui.

\section{Die dilemma van die onderskeid tussen tydgerig en tydgebonde}

Die onderskeid tussen tydgerigtheid en tydgebondenheid binne die hermeneutiek van die GKSA is 'n instrument om te kyk wat in die Bybelteks ' $n$ imperatief daarstel vir die hedendaagse lewe en wat uiteindelik as verpakking van Godsopenbaring kan geld. Dit het in die verlede gehelp om 'n middelmatige kwessie soos kleredrag (hoofbedekking) in die laat sewentigjare op te los (vgl. Coetzee, De Klerk \& Floor, 1980).

Dié onderskeid skep egter probleme in ernstiger sake, naamlik of vroue in die verskillende bedieninge toegelaat behoort te word en of die deelname van aktiewe homoseksuele persone aan gemeenteaktiwiteite verdra moet word. In albei gevalle is daar mense wat hulle beroep op die Bybelteks as tydgerigte Godsopenbaring en mense wat meen dat dít wat die Bybel sê, eerder vir 'n bepaalde konteks gegeld het. ${ }^{1}$ In albei gevalle is dit egter moeilik om agter te kom wanneer iets as tydgerig geld en wanneer 'n teks eerder binne

$1 \quad$ Ek verstaan tydgerig in die sin dat ' $n$ teks altyd in ' $n$ bepaalde tydsverband betekenis het met die oog op 'n spesifieke tydgerigte situasie (Coetzee, De Klerk \& Floor, 1980:17). Binne laasgenoemde skrywers se verstaan beteken dit dat die teks as Gods Woord met tyd verbind is, maar nie daaraan gebind is nie. Die Bybel as Woord van God geld ook in latere situasies, soos wanneer mense in die 21ste eeu die Bybel lees. Die woord tydgerig kan egter verwar word met tydsgebonde, waarvan die antitese tydloosheid is, sodat die term tydgerig die idee van historiese afgeslotenheid bekom, wat dit juis probeer bekamp. Ek weet nie of die term altydgeldend dalk meer bruikbaar is nie. Tydgerigtheid impliseer daar is iets in die teks wat deur tyd bepaal word, maar ook iets wat verby die tydelike gaan. Dan lyk dit vir my egter dat dit wat deur tyd gebind is, nie dieselfde is as wat die tydelike verbysteek nie. Volgens Coetzee, De Klerk en Floor veronderstel tydgerigtheid twee aspekte: 'n kultuur-historiese aspek en 'n altydgeldende aspek. 
'n tydgebonde konteks verstaan word, omdat die eksegete die meeste van die tyd nie hulle eie konteks ook op die tafel sit nie.

Die kwessie van tydgebondenheid en tydgerigtheid is akuut in Fika van Rensburg se Skriftuurlike leiding oor homoseksuele verhoudings in Die Kerkblad van Januarie 2005. Met verwysing na Levitikus 18:22, 1 Korintiërs 6:9, Romeine 1:24-27 en 1 Timoteus $1: 10$ stel hy dat die Bybel duidelik is oor die afkeuring van homoseksuele verhoudings. 2 Van Rensburg gee drie aspekte as toerusting vir 'n kritiese gesprek waarby ek veral by een wil aansluit, naamlik die uitgangspunt dat dit nie hier handel oor kultuur- of tydgebonde uitsprake nie, maar 'n dieperliggende altydgeldende beginsel, te wete seksualiteit wat beperk word tot twee persone van die teenoorgestelde geslag binne die huwelik.

Die vraag is hoe bepaal ' $n$ mens wanneer iets in die Bybel tydgerig of tydgebonde is. Van Rensburg (2005:12) lê twee kriteria aan: (a) die teks behoort dit self aan te dui, en (b) die res van die Bybel moet ook ter sprake wees. Op grond van die teks meen hy dat in die geval van homoseksualiteit, die opdrag in die Bybel self die beginsel word, en op grond van laasgenoemde kriterium meen hy (Van Rensburg, 2005:13) dat die hele Bybel duidelik is dat seksualiteit nie 'n saak van persoonlike voorkeur is nie. As dit kom by die vrou in die amp, dan is dit asof die teenoorgestelde geld. Soos met homoseksualiteit, is Paulus net so duidelik oor die rol van die vrou. Hoekom sou homoseksualiteit 'n altydgeldende beginsel daarstel, maar die rol van die vrou as onderdanige nie? Hoekom sou 'n patriargale sosiale orde wat dwarsdeur die hele Bybel voorkom, nie kon aandui dat sosiale rolle nie 'n saak van persoonlike voorkeur is nie? Uit dié kriteria wat aangewend word om tydgebondenheid of tydgerigtheid te bepaal, kan ek nie 'n bepaalde logika agterkom nie,

2 Hoewel Van Rensburg uit sy pad gaan om die onderwerp simpatiek en pastoraal te benader, het kinders wat hulle homoseksuele geneigdheid openlik erken het, hulle ouers genoop om anders daaroor te dink, en veral hulle siening oor die veroordeling wat vanuit die Bybelteks kom, af te water. $\mathrm{Na}$ aanleiding van die openbaarmaking van sy seun se homoseksualiteit en of hy aanvaar dat sy seun gay is, veral in die lig dat hy as redakteur van Die Kerkbode jarelank die kerk se standpunt teen homoseksualiteit gestel het, antwoord dr. Fritz Gaum in 'n populêre vrouetydskrif die volgende (Els, 2005:51): "Ja. Want net soos dit wreed is om 'n kind wat links is te dwing om regs te skryf, is dit sonde om van 'n homoseksueel te verwag om heteroseksueel te wees. Ek hét geglo homoseksualiteit is verkeerd, maar vandag verstaan ek dat die Bybel nie so duidelik hieroor is nie." By Gaum het die maatstaf van heteronormatiwiteit skynbaar nie meer so 'n groot rol begin speel toe ander maatstawwe te berde gekom het nie. 
buiten duidelike ideologiese voorkeure. Wat uiteindelik 'n groot rol in die keuse speel, so lyk dit, is die leser se subjektiwiteit, wat nie erken word nie.

In hierdie artikel wil ek die volgende aan die orde stel: Die eksegeet maak keuses oor die geldigheid van 'n teks al dan nie vir sy/haar situasies op grond van sekere faktore wat in berekening gebring word. Ten einde verantwoordelikheid vir die keuses te aanvaar, moet die eksegeet in staat gestel word om daardie faktore, oftewel, die redes vir die keuses op die tafel te sit. Op hierdie manier kan 'n etiek van Bybellees gekweek word waar Bybellesers nie bloot net die morele visie van die teks volg omdat dit in die Bybel staan nie, maar kan onderskei tussen dít wat kultureel bepaal en omlyn is en dít wat as geldende beginsels vir die huidige leser gestel kan word. Op dié manier kan 'n mens dalk probeer om eksegetiese willekeur aan bande te lê.

\section{2. 'n Hermeneutiese probleem}

\subsection{Vroue en gays}

By die besprekings en besluite oor die vrou in die amp is "eksegetiese willekeur" nog steeds brandend (vgl. G.F. Snyman, 2002). In Vergeer en Van Rensburg (2003) se beswaarskrif oor sekere sinodebesluite rakende die vrou in die amp, is die agtergrond vir wat hulle beskou as onewewigtige en inkonsekwente hermeneuse juis die probleem van tydgebondenheid en altydgeldende beginsels. In paragraaf 3.2.6 vra hulle of die skynbaar inkonsekwente en rigiede hermeneuse van sommige van Paulus se voorskrifte vir vroue (en die ignorering van ander) nie die indruk kan wek dat die Bybelse geskrifte deur die Sinode willekeurig geïnterpreteer word om vrouelidmate uit die ampte te weer nie.

In 'n rapport oor die rol van die vrou in die kerk (S.D. Snyman et al., 2003), waar daar juis baie klem gelê word op tydgerigtheid, tydgebondenheid en altydgeldende beginsels, word gemeen dat die Bybelteks ' $n$ aanduiding behoort te gee of iets altydgeldend of tydgebonde is (par. 1.11.4).

Die rapport sit tydgerigtheid soos volg uiteen (S.D. Snyman et al., 2003: par. 1.11.1.1-3):

God het die Skrifte in die eerste plek gerig aan mense van daardie tyd, in hulle betrokkenheid by die tyd en plek waarin hulle geleef het. Hy het die boeke van die Bybel dus nie tydloos laat ontstaan nie, maar tydgerig. Te midde van die tydgerigtheid 
van die Skrif het God dit egter ook gegee as Sy openbaring aan alle mense van alle tye. Wat Hy in die Bybel oor Homself en Sy wil van die eerste ontvangers geopenbaar het, openbaar Hy deur dieselfde onveranderlike Bybel aan ons. Daar moet ook onthou word dat nie elke Skrifuitspraak bedoel is om vir alle tye voorskriftelik te wees nie. Die besluit of 'n bepaalde voorskrif blywend is of nie, berus egter nie by die willekeur van die eksegeet nie, maar by wat God self in Sy Woord toelaat. Sosiohistoriese gegewens moet inderdaad in Skrifverklaring in berekening gebring word en dit kan verrykend en ondersteunend inwerk op die verstaan van die Woord. In gereformeerde kringe word dit as 'n onderdeel van die tydgerigtheid van die Skrif beskou. Dit beteken dat die Here Hom oorspronklik in bepaalde tye en lande en kulture en samelewings geopenbaar het, en dat hy dit in bepaalde tale met 'n sekere woordeskat en segswyses laat opteken het vir ons. Die Woord het dus sekerlik in 'n sekere sin 'n verbinding met bepaalde tye en kulture.

Uit 'n bespreking oor die tydgebondheid van die uitsprake in sekere verse (1 Kor. 14:34 en 1 Tim. 2:12), word die volgende gestel (S.D. Snyman et al., 2003: par 1.11.3):

(a) Die Woord is nie aan daardie tye en kulture gebonde nie.

(b) Sosio-historiese gegewens mag nie oorheersend en bepalend op die verklaring van die Bybel inwerk nie, byvoorbeeld wanneer dit wat in 'n bepaalde gedeelte staan, op grond van sosio-historiese gegewens verander of aangepas word.

(c) Bronne wat sosio-historiese gegewens lewer, is nie geïnspireerd nie en dus feilbaar.

(d) Volgens die gereformeerde hermeneutiek word 'n opdrag in die Bybel net as tydelik van aard beskou wanneer die Bybel dit self as sodanig aandui.

Die onderskeid klink amper of dit werk, maar daar is nie kriteria uitgewerk waarvolgens 'n eksegeet kan bepaal wat tydgebonde en wat tydgerig is nie. ${ }^{3}$ Aan die een kant is die Bybelteks vir ernstige

3 Vgl. Van Rooy (2001:51): "In die beredenering van die belang van die gegewens vir vandag, onderskei die sinodale rapport van 1994 [oor die doodstraf - GS] die gevalle waar mense gedood is van die religieuse, morele en seremoniële sake. Die bepalings in verband met laasgenoemde sake word nie meer as bindend vir vandag beskou nie, terwyl die doodstraf vir moord wel 
Bybellesers nie maar net deel van die kultuur van destyds nie (vgl. Breed, 2006:14). So word gemeen dat by die vrou in die amp dit vir Paulus nie om kultuur gegaan het nie, maar oor iets wat God reeds by die skepping vasgelê het.

Aan die ander kant verneem ons van die skepping via 'n teks, wat soos Paulus se briewe, ook binne 'n bepaalde kultuur geskryf is. Genesis het in die sesde eeu v.C. finaal beslag gekry. Om hierdie rede meen Van Niekerk (2006:11) dit is problematies wanneer elemente van die destydse Bybelse konteks waarin die teks geproduseer is, deel gemaak word van die hart van die evangelie. Daardeur word die antieke kultuur normgewend gemaak, terwyl dit nie regtig in die alledaagse lewe die geval is nie.

Die Boek Levitikus is vol maatreëls wat ons vandag nie meer alles navolg nie. Levitikus 19:19 verbied die plant van verskillende gewasse in een akker en 'n rok wat van twee soorte materiaal gemaak is. Terwyl hierdie sake nie meer aanvaar word as geldend nie, word Levitikus se verbod op seks tussen lede van dieselfde geslag wel as geldig beskou (Lev. 18:22 en 20:13). Die Bybel keur ook slawerny goed en om mense met klippe dood te gooi. Maar ons het nie meer slawe nie, en ongehoorsame kinders word nie by stadspoorte gestenig nie (Deut. 21:18-21).

Het 'n mens hier met eksegetiese willekeur te doen? Of is daar iets wat ons noop om nog sekere bepalings te behou, iets wat subjektief is en wat bona fide verswyg word?

\subsection{Gereformeerde hermeneutiek}

Die Bybel as religieuse teks staan sentraal binne die gereformeerde hermeneutiek, sodat dit in enige kerklike diskussie 'n deurslaggewende rol speel (vgl. Van Rooy, 2001:45). Maar verstaan is nie so eenvoudig nie, soos inderdaad blyk uit wat besig is om te gebeur binne die GKSA oor die vrou in die amp. Daar is diegene wat die vrou in die amp wil sien omdat die klassieke rolverdeling van man en vrou aan 'n kulturele konteks gekoppel word wat vir huidige Bybellesers nie meer geldig is nie. Aan die ander kant is daar diegene wat bowe-histories redeneer en dus nie die oorspronklike kontekste in ag neem nie. Vir hulle is die vrou in die amp

behou word [...]. Die betrokke rapport dui egter nie aan waarom sekere sake steeds geld en ander nie" (kursivering - GS). 
problematies. By albei groepe gaan dit egter oor watter deurslag die Bybelteks moet gee.

Dieselfde geld vir homoseksualiteit. Die blote bestaan van gaygemeentes 4 met bevestigde gay dominees binne die SuidAfrikaanse reformatoriese tradisie wys dat ook hierdie mense ernstig is oor hulle geloof. 5 Die Bybel is vir hulle belangrik en hulle slaag daarin om verby die Bybel se verwysings na seksuele omgang met die persoon van dieselfde geslag te kom. 6 Beteken dit noodwendig dat hulle manier van Bybellees gegrond is op 'n afwykende Skrifbeskouing? Van Rooy (2001:54) meen dat verskille in uitgangspunte 'n invloed op interpretasie kan hê. Dit wil egter nie sê dat as mens oor sekere uitgangspunte saamstem, daar tot dieselfde resultate gekom sal word nie. Hy vind dit 'n probleem as verskille in die verklaring en toepassing van die Bybel toegeskryf word aan 'n verskil in Skrifbeskouing.

Hoe gemaak as 'n mens nog die Bybel 'n rol wil laat speel in jou lewe, maar vanuit ' $n$ besef dat 'n paradigmaskuif met verandering in lewenswaardes onherroeplik plaasgevind het? Smit en Vorster (2000:530) antwoord dat wat werklik beginsel is, onverswak behou moet word, maar dat dit met insig in die gees van die tyd "verkoopbaar" gemaak moet word. Hulle meen dat praktiserende gaymense nie deur die kerk met 'n wegkyk en ophaal van die skouer bloot geakkommodeer word nie: "Skriflyne moet, nie wegwerend en afwysend nie, maar liefdevol-pleitend en nadertrekkend deurgetrek

By die Reformerende Kerk in Pretoria word duidelik gestel dat lidmate Jesus as hulle Here moet aanvaar. Hulle glo in Jesus Christus as die Seun van God en hulle verkondig die Bybel. Die Apostoliese Geloofsbelydenis en die Geloofsbelydenis van Nicea word gelees. (Dié kerk spreek haar uitdruklik uit teen gay teologie wat rolmodelle soek in Rut en Naomi, Dawid en Jonatan of Jesus se dissipels.)

$5 \quad$ Al hoe meer stemme gaan op om van gayspiritualiteit iets afsonderliks te maak. Gays wil nie altyd aan dieselfde tafel as die heteroseksuele sit nie, veral nie as dit wat as goed en heilsaam ervaar word, deur ander as 'n gruwel gesien word nie (Boisvert, 1999:61). Hunt (2001:214) spreek haar bedenkinge uit om gays en lesbiërs in heteroseksuele strukture soos die huwelik en die bediening te kry. Haar probleem is dat die model onveranderd gelaat word, terwyl dit juis die model is wat die kerk homofobies laat optree.

$6 \quad$ Hoe lees mense die Bybel te midde van 'n omgewing waar hulle seksualiteit juis as 'n gruwel vir die Here veroordeel word as hulle nie hulle seksuele oriëntasie en geloof kan ontken nie? Vir sommiges funksioneer die Bybel soos wat dit in die Bevrydingsteologie werk, byvoorbeeld M. West (1999:38) wat die Eksodusverhaal as "a coming out story" sien. 
word, met insig in die tydsgees, maar met ferm behoud van die Skrifbeginsels."

Vir Smit en Vorster is die sluitsteen waarop dit aankom Fillipense 1:10: "Onderskei waarop dit aankom." Maar binne die gereformeerde hermeneutiek is daar nie riglyne oor hoe 'n mens dié onderskeid kan maak nie. Met ander woorde, elke leser is op homself of haarself aangewese om dit uit te klaar.

Greijdanus (1946:24 e.v.) erken dit en meen daarom dat die studie van tale en insig in die "gemoedsbestaan en zieleleven" van die volke waaronder die Here sy openbaring gee, bestudeer moet word. Hieronder verstaan hy "Joodsche, geographische, archeologische, historische toestanden en gesteldheden". Oor die mens en die Bybel meen Greijdanus (1946:29) dat die Bybel "geheel menschenwoord en geheel Gods woord" is. Trouens, hy meen dat die Here so groot is dat Hy die mens na eie bestaan en aard en krag kan laat werk om nogtans volkome as sy instrument diensbaar te wees. Die mens is so gering dat hy/sy met al hulle gawes en kragte en werksaamhede niks anders word as om bewuste en verantwoordelike instrument in God se hand tot uitvoering van die Here se welbehae te wees nie.

As dit egter by die verstaan van die die regte sin van die Skrif kom, is Greijdanus minder positief oor die mens. Greijdanus (1946:34) praat van "subjectieve moeilijkheden" wat maak dat die mens ook maar net op menslike manier, menslike vorm en menslike wyse kan ken:

Wij zijn niet God, en worden ook nooit God, ook niet in ons kennen, hoe abstract wij ook zouden redeneeren. Onze kennis van God en van Zijne gedachten en bedoelingen is daarom niet alleen eene van God en Zijne openbaring geheel afhanklijke, en dus eindige, begrensde, zoveel naar inhoud, als wat den vorm aangaat.

Die subjektiewe moeilikheid kom vir Greijdanus voort uit die sonde wat uiteindelik die hele menslike liggaam met al die organe en prosesse aangetas het, sodat ook ons gewaarwording nie meer so fyn en juis en suiwer is nie. Met ander woorde, die menslike verstaan van die Bybel is as gevolg van die sonde van meet af aan problematies.

As laasgenoemde so is, word lesers egter nog steeds gekonfronteer met die Bybel wat gelees moet word. Die gebrekkigheid van die instrumente as gevolg van die sonde hef nie die proses op nie. 'n Leser moet nog kan onderskei waarop dit aankom, dit wat werklik 
beginsel is, dit wat tydgerig is en nie tydgebonde nie. Greijdanus probeer die subjektiewe element uitskakel, terwyl ek meen die subjektiewe element eerder bewustelik verreken behoort te word.

Een subjektiewe element in die gesprek oor gays wat bewustelik verreken moet word, is ons begrip van heteroseksualiteit. Dit word in die gesprekke versluier, omdat die fokus gewoonlik eerder op homoseksualiteit as die afwyking val. Selfs in daardie kringe waar gaydominees toegelaat word, staan manlikheid en heteroseksualiteit voorop. Hunt (2001:216) gaan so ver deur te beweer dat "the combination of male sexual experience, male religious experience and male power models for change is still normative in gay and lesbian religious efforts". In dié verband meen Smith (1999:96) dat al word homoseksualiteit verdra, dit binne die heteroseksuele perspektief steeds 'n problematiese seksualiteit is: "Homosexual orientation is coded against a benchmark of normative heterosexuality to invent a problematic sexuality, that in being graciously 'tolerated', allows heterosexuality to be placed at the 'centre' of the church's patriarchal teachings on Christian tradition, duty and societal familial arrangements." Met ander woorde, die probleem bly "fallogosentrisme". Laasgenoemde hou verband met Jacques Derrida se idee van logosentrisme waarvolgens die sentrum van enige diskoers teruggevoer kan word na die logos (spraak en woorde). Met fallogosentrisme kom die fallus by. Isherwood (2001:251) meen dat die simboliese mag van die fallus nie onderskat moet word nie, want dit definieer wie ons is en waar ons geposisioneer is in 'n heteropatriargiese wêreld. Augustinus is nogal 'n goeie voorbeeld hier.

\section{Heteroseksualiteit}

Augustinus se siening oor seksualiteit, veral in sy geskrif De bono conjugali (Oor die goeie van die huwelik), speel 'n groot rol in die Christelike huweliksetiek. Van Wyk (2002:343) meen dat daar in die laaste deel van die twintigste eeu 'n verandering ten opsigte van die plek en betekenis van seksualiteit binne die huwelik ingetree het, veral ten opsigte van die tipering van seks ter wille van genot. 7

7 Crompton (2003:43, 537) meen dat Philo van Alexandrië "invite[d] mob violence by urging that suspect effeminate men should not be allowed to 'live for a day or even an hour'. Unfortunately, with the ascendancy of Christianity, this deadly tradition which held that all male homosexuals should be ruthlessly exterminated became dogma in European states for some fourteen centuries". 
By Augustinus is daar 'n verband tussen sondeval en seks. ${ }^{8}$ Die seksdaad self is sondig. Die probleem is vir hom die seksdrang wat die mens nie kan beheer of onderdruk nie. Die drang mag natuurlik wees, maar dit word nietemin deur die sonde aangetas.

In die geskrif De bono conjugali sê hy dat om te trou goed is, maar maagdelikheid is beter (Augustinus, 1988: b. conjug. 9). Seks is nodig vir voortplanting soos wat kos nodig is om honger te stil. Om kos vir iets anders te gebruik, is verkeerd. Seks wat nie voortplant nie, is dus ook verkeerd. Seks is weliswaar deel van die huwelik, maar dit is nietemin sonde. In vergelyking met ontug is dit ten minste meer vergeeflik as laasgenoemde wat op wellus gegrond is (Augustinus, 1988: b. conjug. 11). Sonder seksuele aktiwiteit sal die verhouding tussen man en vrou 'n vriendelike en werklike verhouding wees waar die een regeer en die ander gehoorsaam (Augustinus, 1988: $b$. conjug. 1). Trouens, 'n vrou se verhouding met haar man is soos dié van 'n slaaf tot sy meester of dié van 'n siel tot God.

Hierdie skema van regeerder en onderdaan bepaal wat Augustinus dink van seksualiteit. Hy skep 'n hiërargie van sonde (Augustinus, 1988: b. conjug. 8): die ergste is onnatuurlike seks, dit wil sê seks wat nie lei tot die verwekking van kinders nie; daarna kom bloedskande, veral met die moeder, gevolg deur owerspel, ontug of seks met 'n prostituut, en laastens seks binne die huwelik (vgl. Brooten, 2003:187). In Augustinus se hiërargie van seks blyk in sommige gevalle dat seksuele verkeer met 'n prostituut "minder sondig" is as seks met 'n vrou binne die huwelik. Byvoorbeeld (Augustinus, 1988: $b$. conjug 11) indien die man contra naturam handel, soos in anale seks, dan is seksuele verkeer met sy eie vrou execrabilius, oftewel, meer skandalig as wanneer dit met 'n

8 Daar is nogal 'n ooreenkoms tussen Greijdanus se siening oor die gevallenheid van die mens en Augustinus se idee van die sondeval en seks. Greijdanus (1946:36) meen dat "bij den mensch de zonde met Gods vloek over haar niet enkel verstoring bracht over en in ons lichaam, en zijn bestaan en zijne werking, maar dat zij evenzeer onze ziel, onzen geest, aangreep, knakte, verdierf, voor wat haar zoeken en begeerten en streven aangaat, en voor hetgeen hare vermogens en functies aangaat. $\mathrm{Zij}$ bracht verwarring en verwoesting aan in ons verstand en in onzen wil. En ook deswege is ons gewaarworden en waarnemen en voorstellen en onze begripsvorming, onze verbeelding en heel ons kennen en redeneeren, niet in vollen zin en omvang scherp en zuiver en recht, doch in meerdere of mindere mate onjuist, verward, onwaar." Soos menslike verstaan vir Greijdanus sondig is, is die seksdaad vir Augustinus ook sondig. 
prostituut gebeur (execrabiliter). Op hierdie manier probeer Augustinus die eer van die vrou binne die huwelik beskerm.

Brooten (2003:191) oordeel egter soos volg oor Augustinus se siening:

Building on the dual values of female subordination and female shame, Augustine's system allows for the prostitution of women, for spousal rape, and for polygyny (where it is culturally acceptable and promotes procreation). None of these is contrary to nature or to law in Augustine's system.

Dit wat natuurlik is, blyk op die ou end kultureel bepaald te wees. Die stelsel is hiërargies met ' $n$ baie spesifieke verstaan van wat manlikheid en vroulikheid binne 'n bepaalde kulturele opset behels. Mans voer die botoon en vroue is minderwaardig en onderdanig. Hierdie minderwaardigheid en onderdanigheid word egter as natuurlik gesien. Wat natuurlik is, word gewoonlik universeel en onveranderbaar (Brooten, 2003:193). Augustinus regverdig die aartsvaders se poligamie deur te verklaar dat dit wat natuurlik is, nie sonde is nie. Die aartsvaders het ter wille van kinders meer as een vrou gehad, meen Augustinus (1988: b. conjug 25). Hy voeg egter by dat dit in daardie tyd die gewoonte was en dat dit deur geen wet verbied was nie. Bloedskande word eweneens as onwettig gekonstrueer, maar is nie so immoreel as onnatuurlike dinge nie (Augustinus, 1988: $b$. conjug 8). Laasgenoemde is dinge wat té erg is om oor te praat.

Die retoriek van die natuurlike is baie sterk en word tot vandag toe as oortuigend beskou. Die idee wat 'n mens kry, is dat solank die aktiwiteit met die gepaste liggaamsdele in 'n wettige verhouding, met suiwer gedagtes en vir die regte redes gedoen word, daar nie aktief gesondig word nie (vgl. Ramshaw, 2003). Toe wedersydse respek binne 'n liefdevolle verhouding by dié mengsel bygevoeg is, is seks as 'n gawe van God beskou om die band van liefde en intimiteit tussen twee mense te verstewig. Desondanks is kultuur en die gemeenskap buite rekening gelaat, sodat die sosiale konstruksie van liefde en verwantskap as magswerklikhede nie in die spel gekom het nie.

Die magswerklikheid van seksualiteit beïnvloed ons siening van seksualiteit wesenlik. Met die argument van die natuurlike, dui 
heteroseksualiteit9 die eroties-korrekte posisie aan. Die biologiese bestemming van die fallus is die vagina. Die gebruik van anatomie om tussen geslagte te onderskei, maak die onderskeid tussen mans en vroue onvermydelik. Op sosiale vlak beteken dit egter dat daar 'n ongelyke magsverhouding van mans oor vroue ontwikkel het, deurdat aan vroue 'n kultureel-beperkte plek in die seksuele verdeling van die reproduktiewe arbeid toegeskryf is.

Binne hierdie heteronormatiewe ideaal het prokreasie aan die einde van die 19de eeu op die agtergrond begin tree, terwyl die genotsbeginsel al hoe meer na vore getree het. Volgens Katz (1995:51) was dit die genot van die man wat in die visier was, sodat heteronormatiwiteit as heteropatriargie gefunksioneer het. Vroue moes hulle steeds aan die fallus onderwerp en mans wat dit gedoen het, het dit hotagter gekry. Met die fokus op die man, kon laasgenoemde die mag behou. Om hierdie rede was dit ook nodig om die onderskeid met die homoseksueel te behou, soos Katz (1995:112) dit stel: "a sexual solid citizen and a perverted unstable alien, a sensual insider and a lascivious outsider, a hetero center and a homo margin".

Die nadraai van die Tweede Wêreldoorlog het gehelp om heteroseksualiteit as 'n duidelik-aanwysbare ordeningsbeginsel in die samelewing te vestig met die hulp van die argument oor dit wat natuurlik is. Ná die oorlog het die mans van die slagveld na die fabrieke teruggekeer en die vroue het van die fabrieke huiswaarts gekeer. In wat gesien word as 'n natuurlike onderskeid, is sosiale rolle gekonstrueer op grond van anatomie. Katz (1995:123) meen hierdie toedrag van sake het van heteroseksualiteit 'n onderdrukkende stelsel gemaak. Mans is bevoordeel en vroue is bloot as aanhangsels beskou. Vroue was op mans aangewese: hulle moes hulle bevrediging en erkenning in die man soek, sodat 'n vrou nie verniet Mevrou Dominee of Mevrou Dokter of Mevrou Professor geheet het nie.

Met die toetrede van vroue tot die arbeidsmark, het volgens Katz (1995:183) 'n nuwe seksualiteit ontwikkel. Vroue se finansiële

$9 \quad$ Heteroseksualitieit is aanvanklik nie as die teenpool vir homoseksualiteit gebruik nie, hoewel die twee terme in min of meer in dieselfde asem gebesig is. In 1892 is albei begrippe aangewend om bepaalde soort perversies aan te dui, naamlik die abnormale manifestering van seksuele begeerte (Katz, 1995:19). By Freud het heteroseksualiteit gestabiliseer as die normatiewe ideaal, met homoseksualiteit wat die afwykende norm daarstel. 
onafhanklikheid het seksuele onafhanklikheid tot gevolg gehad. Mans kon van verkragting binne die huwelik aangekla word en vroue het nie meer penetrasie nodig om swanger te raak nie. Boonop veroorsaak die vrylike beskikbaarheid van geboortebeperkings 'n radikale skeiding tussen prokreasie en genot. Ook het die onderskeid tussen heterosekualiteit en homoseksualiteit begin vervaag. Nuwe gesinstrukture as gevolg van egskeiding is ewe onstabiel as wat aan homoseksuele verhoudings in kulturele, godsdienstige en regsterme toegeskryf word. Die erotiese dade verskil ook nie veel nie, behalwe ten opsigte van die geslag van die partye.

Biologiese bepaaldheid plaas die probleem in die liggaam en nie in die gemeenskap nie. Katz (1995:189) meen egter dat biologie nie die erotiese eindbestemming kan bepaal nie, want seksuele anatomie bepaal op die ou einde ook nie geslagsrolle nie. Laasgenoemde word deur die gemeenskap gekonstrueer en is dus veranderbaar.

Hoe kom 'n mens egter verby common sense en die argument van die natuurlike wat die alledaagse gesprekke oor seksualiteit beïnvloed? Common sense vertel aan ons dat die wêreld verdeel word tussen manlik en vroulik, seuns en meisies, mans en vroue! Met sulke common sense het 'n persoon 'n "untutored, nononsense, matter-of-fact"-houding teenoor die wêreld, meen Elliot (1998:37): "The difference lies in our basic apprehensions of the obvious, the way life is, once stripped of artifice and theory and intellectual pretensions: the things anyone knows (or at least anyone with a lick of sense)."

\section{Logika by die tekste self}

As alles so toeganklik is, so feitelik en duidelik vir almal om te sien, hoekom is dit nodig om die argumente te vertroebel met ' $n$ onderskeid tussen tydgebondenheid en tydgerigtheid? Die tekste wat Van Rensburg aanhaal, is immers duidelik: seksuele omgang tussen lede van dieselfde geslag word afgewys.

Botha (s.a.:22) meen dat hierdie tekste vanuit die skepping verstaan moet word, want God het heteroseksuele verkeer bedoel en die tekste argumenteer anatomiese komplementariteit. Terseldertyd meen hy ook dis geregverdig om 'n moderne term soos homoseksualiteit in die tekste in te lees, want die homoseksuele 
daad definieer die inhoud van so 'n verhouding, ongeag wat dit genoem word (Botha, s.a.:90). ${ }^{10}$ Deurdat Botha nie sy eie ideologiese konteks op 'n sosio-historiese wyse verdiskonteer nie, lyk dit egter of hy eenvoudig moderne sienings van seksualiteit in die Bybel inlees. Op só 'n manier word daar nie regtig geregtigheid teenoor die tekste bewys nie, omdat nóg die tekste nóg die leser regtig binne 'n eie historiese konteks ontleed word (vgl. SchüsslerFiorenza, 1988).

As 'n mens binne die gereformeerde hermeneutiek wil bly en gesag aan die tekste wil toeskryf, moet dié tekste ernstig opgeneem word. Deurdat die ideologiese bril waarmee die tekste aangewend word nie deursigtig is nie, word gesag selektief toegedig. 'n Voorstander van gayregte in die kerk, Walter Wink (1994), erken byvoorbeeld dat die Bybel negatief is oor homoseksuele gedrag, maar meld dat van die 20 seksuele voorskrifte in Levitikus nog net vier nagevolg word. Sestien voorskrifte geld nie meer nie! So sou 'n mens van die voorskrifte kon byvoeg, soos slawerny wat in die Bybel goedgepraat word, maar vandag as immoreel afgewys word. Of selfs apartheid wat met behulp van Israel se afgesonderdheid 'n staanplek onder groot gereformeerdes van die vorige eeu se denke ontvang het.

Die probleem met baie tekste in die Bybel is dat die omgewing waarin hulle eens gefunksioneer het, drasties verskil van die omgewing waarbinne ons die tekste wil laat funksioneer. Die gevolg is dat ' $n$ teks se netwerk van verhoudings wat die teks in 'n latere konteks kon dra, verdwyn het. Ek dink dit is wat gebeur in die geval van homoseksualiteit en daardie Bybelse tekste wat geslagtelike omgang tussen lede van dieselfde geslag afwys. Hierdie tekste word gelees met behulp van 'n moderne begrip van heteroseksualiteit as norm wat na die skepping teruggeprojekteer word.

Botha se hermeneutiek is problematies. Hy (Botha, s.a.:16) erken dat dit noodsaaklik is om van die Bybelse milieu ' $n$ sosio-historiese konstruksie te maak. In 'n voetnoot sê hy die volgende: "Cultural milieu as a meaning-giving context includes the totality of the conditions under which people live. It includes material conditions, education, the ways their psychological needs are met or not met, their socio-economic efforts and relationships with people and groups, institutional influences, religious beliefs, normative symbols, ideas and other spiritual aspects, the expression of sexuality within the community and behavioural patterns." Sy objektivistiese hantering van die Bybel as ' $n$ stoorkamer van feite en beginsels, weerspreek egter hierdie goeie bedoeling. 


\subsection{Levitikus}

Levitikus is 'n voorbeeld van hoe 'n teks se netwerk van verhoudinge in 'n latere konteks verdwyn. Die uitsprake in Levitikus oor seksule omgang tussen mans verskyn as deel van 'n lys seksuele sondes, soos bloedskande, bestialiteit, seksuele omgang met 'n vrou wat menstrueer en kinders wat aan Molog geoffer word. Al hierdie dade het 'n bedreiging ingehou vir die integriteit van Israel se nageslag (bloedskande, owerspel) of kom neer op 'n vermorsing van die semen van Israel.

Daar is ' $n$ bepaalde logika met twee moontlikhede agter hierdie wette:

- Davies (1995:321) gaan van die standpunt uit dat Genesis 1:2728 taamlik sentraal tot die verstaan van die Priesterlike dokument is: die mens as skepsel van God moet vrugbaar wees, vermenigvuldig en die aarde onderwerp. Dit beteken egter dat aborsies en voorbehoeding onaanvaarbaar is, want kinders is ' $n$ goddelike seën. Verder moet daar sterk moeders wees wat gedurig in kraam is om gesonde seuns te baar. Maar om 'n groterwordende bevolking te kan onderhou, moet daar voortdurend ekstra land verkry word en dit wat hulle besit, moet verdedig word. Die Priesterdokument is die enigste een wat Israel beveel om 'n militêre kamp te maak. Omdat die vroue by die huis is met die kinders, is dit net mans wat binne militêre geweld gesosialiseer word. Maar só iets skep probleme en daar moet teenmaatreëls getref word om manlike geweld in die samelewing teen te staan. Omdat seksuele omgang van dieselfde geslag in uitsluitlik manlike groepe floreer, maak dit sin dat die Priesterlike geskrif, wat Israel in militêre eenhede organiseer, en wie se oogmerk dit is om die bevolking te laat vermeerder, praktyke wat prokreasie teenwerk, sal verbied.

- Mohrmann (2004) sien die logika van Levitikus 18 in 'n drieledige struktuur wat verhoudings reguleer in terme van die gesin, die stamverband en die volksverband. Met ander woorde, seksuele verhoudings word gereguleer van die intieme (die gesin) na die uiterlike en politieke grense van Israel, Egipte en die Kanaäniete. Die verbod op seksuele omgang tussen lede van dieselfde geslag vorm deel van die bepalings wat uiterlike grense daarstel. Mohrmann (2004:75) stel dit soos volg:

The organizing scheme for vv. 6-23 overall is its progression of sexual laws, which it implicitly achieves through the body's symbolic representation of cultural boundaries. The implied 
meaning of the sexual laws was a strategy to circumscribe life through multiple layers of boundaries. To organize these laws in this manner expresses a goal which was and is most important in relationships with cultural competitors.

Te midde van oorbevolking wat volgehoue prokreasie daarstel en globalisering wat kulturele grense laat vervaag het, maak die voorskrifte in Levitikus nie meer sin nie.11 Trouens, die verstaan van homoseksualiteit sedert die laat 19de eeu noop iemand soos Eilberg-Schwarz om in die voorskrifte problematiese godsdienstige gevolge raak te lees.

\subsection{Verhouding met Jahwe}

Die voorskrifte begin en eindig met die opdrag om nie die maniere van die Egiptenare en die Kanaaniete na te boots nie (EilbergSchwarz, 1994:93). Dit lyk dus of seksuele omgang tussen mans iets is wat vreemd was vir Israel en met 'n heidense volk geassosieer word, wat uiteindelik in Israel se geskiedenis as immoreel gestereotipeer word. Met ander woorde, seksuele omgang met dieselfde geslag behels iets van afgodery.

Israel se verhouding met Jahwe word ook in seksuele terme beskryf.12 Boonop is dit 'n verhouding van mans met 'n manlike godheid.13 Botha (s.a.:17) meen dat die onderskeid tussen geslagte

11 Human (2005:635) gaan so ver om te verklaar dat die gebruik van tekste soos Levitikus 18 en 20 anatema vir die homoseksuele debat verklaar behoort te word, omdat dieselfde-geslag-seks van die Ou Nabye-Ooste nie dieselfde is as wat vandag met homoseksuele oriëntasie bedoel word nie. Human (2005:630) meen in die lig van die omgewing en Sitz im Leben het die Bybelse tekste, wat in die debat oor homoseksualiteit betrek word, ' $n$ ander funksionaliteit as wat aan hulle in die debat self toegedig word.

12 Eilberg-Schwarz se siening het my laat wonder oor ' $n$ ondertoon in die openbaringsgeskiedenis van die Bybel wat in die woord gemeenskap opgesluit lê. In hierdie benadering word baie klem gelê op "verbondsgemeenskap" of "in gemeenskap met God te lewe". "God voer sy heerskappy en sy gemeenskap met die mens deur ondanks die groot tekortkomings wat so tipies van die mens se lewe is" (Helberg, 1983:45). Dit dui op 'n verhouding wat baie intiem is, soos tussen twee mense wat hierdie verhouding ook liggaamlik uitleef.

13 "The Israel that is collectively imagined as a woman is actually constituted by men - men like Moses and the patriarchs. And these men love, in ways that are imagined erotically and sensually, a male deity.[...] In the culture of ancient Israel, woman was imagined as the natural counterpart of man, and sexual acts between men were condemned. Thus, at the heart of this religious system was a deep tension in defining masculinity. Men were complementary to women; 
'n skeppingsgegewe is, want daar is geen seksuele onderskeid op goddelike vlak nie. Hierteenoor meen ek dat God nooit van sy geslagtelikheid ontneem word nie. Met die wegval van Ashera en Astarte in die monoteïsme, het Jahwe as't ware 'n vrygesel geword.14 Jahwe, as die enigste God, het geen seksuele maat nie.

Israel word hierdie maat egter in feite, sodat Jahwe jaloers waak, soos wat ' $n$ man jaloers is as hy sy vrou van owerspel verdink (Eilberg-Schwarz, 1994:121). Maar om met Jahwe in 'n verhouding te wees, moet Israel as't ware vervroulik. Die mans word as't ware ontman. By die aartsvadergeskiedenis is dit Jahwe wat die vroue laat swanger word. Goddelike manlikheid voer die botoon. As Moses God op die berg ontmoet en hy terugkeer, moet hy soos 'n vrou 'n sluier dra, want sy gesig gloei. Telkens wanneer mans God ontmoet, kom hulle manlikheid in gedrang. 15 Eilberg-Schwarz (1994:160) interpreter dit soos volg: "If that encounter [between men and a male God - GS] is not handled properly, through a sacrifice of human masculinity and a symbolic submission to a dominating male God, then the human male is eliminated."

Maar wat het dit alles met homoseksualiteit te maak? Dit lyk asof 'n mens hier te doen het met 'n skema van dominering en onderdanigheid. In terme van die godsdiens moes die mans hulle aan Jahwe onderdanig stel. Hulle het dit gedoen deur Jahwe se "vrou" te word. Om dit egter in die werklike lewe te doen, sou beteken dat een van die mans sy posisie van dominansie verloor. So iets is egter ondenkbaar in terme van die sosiale orde wat gegeld het, omdat 'n man sonder mag net sowel gekastreer kon gewees het.

marriage was a return to primordial unity. At the same time, a man's relationship to God was conceptualised as loving and sensual" (Eilberg-Schwarz, 1994:3).

14 Boshoff (2000:100-106) verwys na inskripsies wat by Kuntillet 'Ajrud gevind is waar Jahwe in Samaria waarskynlik aan 'n vroulike godheid verbind is, naamlik Ashera.

15 Wanneer Jakob met die man van God worstel, word hy op die heup geslaan. Maar die heup is 'n eufemisme vir die manlike geslagsdeel (Eilberg-Schwarz, 1994:155). By 'n beslissende oorgangstyd in Jakob se lewe waar hy hom losmaak van sy moeder en onafhanklik begin funksioneer as man, word hy deur Jahwe aan sy geslagsdeel gegryp om daardeur sy onderdanigheid aan hom te betoon. By Moses gebeur dieselfde aan die vooraand van die verlossing uit Egipte. Hy worstel met 'n man van God, maar waar Jakob in sy geslagtelikheid getref word, is dit Moses se seun wat die besering ervaar. Dis eers as Moses se vrou die seun besny, dat die aanval afgeweer word. 
Wat wel duidelik is, is dat die voorskrifte rondom naaktheid en seksualiteit binne 'n bepaalde sosio-historiese omgewing en wêreldbeeld gefunksioneer het (vgl. Cothey, 2005:150-151). Die probleem is net dat nie een van die twee meer gedeel word nie. Dit maak ' $n$ beroep op die Bybelteks bloot outoritêr, 'n gesag wat afgedwing moet word. Sonder 'n netwerk van verhoudings wat die teks in 'n latere konteks kan dra, verloor die teks oorredende gesag.

\subsection{Geslagtelike omgang as resultaat van afgodery}

Dit lyk ook nie of Paulus se spesifieke en ondubbelsinnige afwysings oor seksuele omgang tussen lede van dieselfde geslag deur ' $n$ netwerk van verhoudings in 'n latere konteks gedra kan word nie (Davies, 1995:328). Davies (1995:318) meen dat die afwysing by Paulus gemik is op dit wat aan die Judaïsme binne die Hellenisme aanstoot gee, naamlik afgodery wat aanleiding gegee het tot seksuele omgang met dieselfde geslag.

Volgens Davies begrond Paulus sy afkeer vanuit die Tora. Dié Joodse geskrifte het dit egter nie oor natuurlike en onnatuurlike dade nie, maar of die dade aan die eise van die Here voldoen. Paulus se gebruik van natuurlik en onnatuurlik sinspeel eerder op die Griekse filosowe se siening van seksuele omgang wat nie op prokreasie afgestem is nie en derhalwe onnatuurlik is. Seksuele omgang met die oog op kinders is natuurlik. Dit beteken dus dat ' $n$ man 'n vrou mag los as sy nie kinders kan baar nie. En as hy met so 'n vrou trou, wel wetende dat sy nie kan kinders kry nie, is seksuele omgang met haar ook onnatuurlik. ${ }^{16}$

Daar is egter ook 'n ander siening waarvolgens Paulus se afwysing van seksuele omgang met persone van dieselfde geslag dalk meer verband hou met heidense onreinheid as met die sondeval soos wat tradisioneel gedink word (vgl. Martin, 1995:338). Hiervolgens sou Paulus sinspeel op 'n Joodse mite oor afgodery. Dié mite verklaar hoekom 'n sekere beskawing nie meer bestaan nie. In dié mite word die gevolg van afgodery verbind met seksuele omgang tussen mans as straf van die Here. Met ander woorde, hierdie heidense

16 Hoewel Paulus suggereer dat kinders kry natuurlik is, meen hy tog dat die selibaat beter is. In alle geval, gegewe die komende wederkoms, is kinders nie meer so belangrik nie. Maar Davies (1995:328) meld ook dat Paulus in alle geval nie opgewonde is oor enige seksuele verhouding nie. Oor die liefde tussen man en vrou is hy maar stil en hy sou dus ook nie liefde tussen persone van dieselfde geslag kon raaksien nie. 
onreinheid is die gevolg van afgodery en het seksuele omgang tussen mense van dieselfde geslag tot gevolg. As 'n mens dus Paulus se logika moet deurtrek, dan beteken dit dat seksuele omgang tussen mense van dieselfde geslag nie meer sal plaasvind as daar nie meer afgodery en politeïsme is nie.

Wanneer die Bybel se voorskrifte oor seksuele omgang met persone van dieselfde geslag gebruik word om 'n sekere soort moraliteit daar te stel, dan het die verbod net nie meer dieselfde trefkrag as wat dit toentertyd gehad het nie. Die netwerk van betekenisse en norme waarbinne dit eens gefunksioneer het, het verdwyn. Omdat die tekste egter 'n strukturele resonans vind met ons siening van heteroseksualiteit, word heteronormatiewe beginsels teruggeprojekteer na die Bybelse tekste.17 Die gevolg is dat ons hierdie antieke tekste gebruik sonder om die logika van die argumente van die skrywers (soos Paulus en die skrywer(s) van Levitikus) na te speur. Dit merk ' $n$ mens ook in die rol wat die skeppingsverhaal in die argumente oor heteroseksualiteit speel.

\subsection{Die skeppingsbeginsel, heteroseksualiteit en intersekualiteit}

Heteroseksualiteit word teologies in die skeppingsverhaal (Gen. 1:27-28) begrond: God het man en vrou geskape en weliswaar na sy beeld.18 Dié soort regverdiging ondervind egter probleme vanuit die nuutste biologiese navorsing wat 'n absolute onderskeid ondergrawe. Binne die biologiese wetenskappe word eerder van 'n kontinuum gepraat, want dit gebeur dat party mense na een geslag $l y k$, terwyl hulle chromosome suggereer dat hulle aan 'n ander

17 Stiebert en Walsh (2001:146) meen dat die Bybelse tekste wat handel oor seksuele omgang tussen lede van dieselfde geslag nie handel oor seksuele oriëntasie nie, maar oor die vestiging van manlike oorheersing, waarvan seksuele penetrasie die manier is om heerskappy te vestig.

18 Botha (s.a.:16-17) meen die volgende: "From the beginning mankind [sic] was created only as male and female, a fact that will be important for our interpretation of the New Testament understanding of sexuality." Voorts meen hy dat die Bybel nie in 'n vakuum ontstaan het nie en dat 'n sosio-historiese konstruksie van die Bybelse milieu van lewensbelang is om die betekenis van ' $n$ teks te bepaal. Nêrens gee hy egter blyke van 'n sosio-historiese ontleding (hoe kort ookal) van die skeppingsverhaal waarop hy sy verstaan van die Nuwe Testament baseer nie. Die skeppingsverhaal word bloot dogmaties aangewend. Hoewel hy erken dat dit van die uiterste belang is om 'n sosio-historiese ontleding van die Bybel te maak, meen hy dit is nie nodig in die geval van die leser self nie. Nêrens gee hy ' $n$ aanduiding dat hy die leser se konteks self ontleed en daarmee sy eie denkraamwerke op die tafel plaas nie. 
geslag behoort. Die onderskeid van man en vrou wat gebaseer is op anatomiese voorkoms as skeppingsordinansie, het nie raad met iets soos interseksualiteit 19 nie.

Interseksualiteit as mediese probleem spruit voort uit die afdwinging van heteronormatiwiteit. Hiervolgens moet aan 'n pasgebore baba 'n geslagtelike identiteit toegeskryf word. Indien dié identiteit onduidelik is, word aanvaar dat die baba wel 'n ware identiteit het, maar dat dit eers by verdere ondersoek bepaal kan word. Die mediese wetenskap fokus op ovariese en testikulêre weefsel as heuristiese sleutels om die liggaam se seksuele identiteit te bepaal.20 Heteroseksualiteit vereis dat ' $n$ liggaam per definisie in een van twee kampe inpas, ongeag hoe onduidelik die res van die seksuele anatomie is.

Daar word uitgegaan van die veronderstelling dat daar 'n regte manier is om 'n man en 'n regte manier om 'n vrou te wees. Kinders wat hierdie veronderstelling uitdaag, word chirurgies gerekonstrueer om die paradigma waar te maak. In die protokol van die behandeling van interseksualiteit word heteroseksualiteit bloot gesien as vaginale penetrasie.

Interseksualiteit gaan ons common sense te bowe. Bitter min mense sal dit erken wanneer ' $n$ baba se seksuele organe dubbelsinnig of dubbelslagtig is. Maar common sense word sosiokultureel bepaal. In die Dominikaanse Republiek het kinders wat aan 'n gebrek aan testosteroonmetabolisme ly, 'n spesiale status as guevedoce. Hulle is kinders wat as meisies grootgemaak word, net om by puberteit as mans te ontwikkel. Wat vanuit 'n heteroseksuele perspektief bloot 'n verkeerde identiteit is, is vir die gemeenskap 'n derde seksuele kategorie (vgl. Elliot, 1998:36). Indiane in Navaho het ook 'n derde

19 Dreger (1998:26) definieer interseksualiteit soos volg: "[l]ntersexuality constitutes a range of anatomical conditions in which an individual's anatomy mixes key masculine anatomy with key feminine anatomy." Daar is meer as 25 toestande geïdentifiseer (vgl. Hester, s.a.:4-6). Een van die probleme is om te bepaal wat normaal is en wat nie. Hester (s.a.:23) meen die volgende: "One of the reasons for this murkiness is that there is no medical standard of gender assignment and genital appearance that isn't also entangled with cultural, and even personal, aesthetic notions of how the genitals should properly look and function." Dié benadering beteken dat interseksualiteit nie 'n mediese probleem is nie, maar' $n$ kulturele probleem wat deur die mediese professie beheer word.

20 Dreger (1998:26) sê die volgende: "By equating sex identity simply with gonadal tissue, almost every body could be shown to be a true male or a true female in spite of mounting numbers of doubtful cases." 
kategorie wat hulle nadleeh noem. Sulke interseksuele mense het ook ' $n$ bepaalde status as heiliges gehad. Hulle was gewoonlik stamhoofde, omdat hulle die werk van 'n man en 'n vrou kon doen.

Interseksualiteit is in die Joodse tradisie ook nie onbekend nie.21 Binne die Talmud is daar ' $n$ tradisie wat aan Adam in Genesis 1:27 'n dubbelslagtigheid gee. Die eerste verklaring neem die vertrekpunt uit die verhaal van Eva wat uit Adam se rib gevorm is. Die Hebreeus vir rib (tsela) word ook soms vertaal as sy (Eks. 26:20) of gesig of stert. Tsela dui op 'n ekstra deel van Adam wat bedoel is om 'n vrou te word. Met ander woorde, volgens Horowitz (1979:186), het Adam albei geslagte ingesluit, totdat Eva van hom geskei is, amper soos ' $n$ Siamese tweeling. 'n Ander Talmudtradisie verstaan dat Adam twee gesigte gehad het, een voor en een agter. Eva het uiteindelik die agterste gesig uitgemaak. Om hierdie rede het 'n man nooit agter 'n vrou geloop nie.

Maar daar is ook ' $n$ ander begronding wat berus op die voorkoms van die derde persoon voornaamwoord enkelvoud en nie die meervoud nie. In 'n tekstuele tradisie van die LXX (in Meg. 9a) word Genesis 1:27 vertaal soos volg: "Manlik en vroulik het Hy hom gemaak" en nie "Manlik en vroulik het Hy hulle gemaak" nie. Die Christelike tradisie het egter die meervoud gebruik en sodoende adam as interseksuele mens verwerp, sê Horowitz (1979:186).

Vanuit queerkritiek kom dié soort verstaan van Genesis 1:27 handig te pas. Sally Gross (1999) maak 'n groot saak daarvan dat Genesis 1:27 nie so eenduidig is oor die tweedeling van man en vrou nie. Die skuif van die enkelvoud hom, oto, om te pas by adam, na otam, hulle, om te pas by die meervoud hulle, val vir haar vreemd op. Sy (1999:71) vind Rabbi Jeremia se verklaring 22 aanvaarbaar in Ber. R. 8: "Rabbi Yirmiyah ben Elazar said: When the Holy One Blessed be He created the primal man [the primal Adam], he created him an androgyne, and it is therefore said: male and female he created them (Gen. 1.27)."23

21 Die Christendom het dit egter vroeg al verwerp. Luther sou selfs gesê het sulke tekste in die tradisie wys net op die duiwel se kwaadwilligheid (vgl. Horowitz, 1979:184).

22 "Sulke kinders word gewoonlik as meisies grootgemaak wat by puberteit as mans ontwikkel."

23 'n Interseksuele interpretasie van die LXX-weergawe van Genesis 1:27 was deel van die hoofstroom antieke Judaïsme en die Midrash Rabbah haal Rabbi 
Vir Gross (1999:71) suggereer dié siening dat die gebruik van Genesis 1:27 as steun vir 'n vlymskerp verdeling van die mensdom in manlikheid en vroulikheid, nie heeltemal gepas is nie. Daar is dus mense wat tussenin val. 24

Die bestaan van interseksualiteit (al is die voorkoms minder as 10 persent in die bevolking) maak dit moeilik om die beginsel van tweedeling van manlik en vroulik binne 'n biologiese bepaaldheid te behou. Interseksuele persone pas nie in 'n raamwerk waarvolgens die manlike en vroulike verskillende reproduktiewe take het nie, en gevolglik ook verskillende fisiese, kognitiewe en gedragskenmerke moet hê om hulle in staat te stel om hulle voortplantingstaak die beste te kan uitvoer nie (vgl. Looy, 2002:12).

Die uitdaging is om die aard van seksualiteit, gender en seks in die lig van interseksualiteit in heroorweging te neem. Die huidige teologiese skema forseer die interseksueel om deel te word van 'n paradigma teen fisiese en psigologiese koste. 'n Persoon wat afwyk van die heteroseksuele norm vra hulleself af of hulle pervers, siek of net anders is. Heather Looy (2002:10) noem die volgende probleem van 'n man wat as baba verander is van vroulik na manlik: "To the extent that he experiences himself as female, and finds himself attracted to both males and females, is his marriage in part a homosexual relationship? Do the categories of female/male, homo/heterosexual make any sense for intersexed persons?"

Moet 'n mens dalk nie ekstra kategorieë bedink waar manlikheid en vroulikheid nie so rigied essensialisties en universeel benader word nie, en waar om na die beeld van God geskape te wees nie beteken

Jeremia, seun van Elieser, aan vir die siening dat Adam oorspronklik interseksueel was.

24 Numeri 5:3 stel vir haar ook eerder'n kontinuum voor en nie 'n blote teenstelling nie; mi-zakhar ve-ad neqevah, van man tot vrou. Abraham en Sara word as interseksueel beskou in Jesaja 51:1-2. Albei was 'n tumtum en Sara daarby 'n aylonith. Vir Gross (1999:72) is albei begrippe interseksuele kategorieë. ' $n$ Tumtum is iemand wie se fisiese geslag onbepaalbaar is, want daar is nie genitalië nie; 'n aylonith is 'n vrou sonder 'n baarmoeder, iemand wat lei aan androgene onsensitiwiteitsindroom (Gross, 1999:72). In Jesaja 51:1-2 word gesê dat Israel hulle bestaan aan God te danke het, wat hulle uit rots gekap het en uit die holte van 'n steengroef gegrou het. Volgens Gross (1999:73) word hier 'n suggestie gelaat dat die Here 'n struikelblok in die natuur van Abraham en Sara moes oorkom om 'n nageslag te verwek. Hulle was, in die woorde van Gross (1999:73) "congenitally incapable of procreation by nature". 
dat heteroseksueles na die heteroseksueel-patriargiese beeld van God gemaak is nie? 25

\section{Seksualiteit en performatiwiteit}

Omdat ek aanneem dat seksualiteit 'n meer komplekse aangeleentheid is wat nie met anatomie as bestemming opgelos kan word nie, vind ek eerder aanklank by Judith Butler (1993) se idee van performatiwiteit (performativity). Dus norme gee aan liggame hulle stoflikheid of stoflike betekenis (materiële werklikheid). Performatiwiteit word verstaan as die gedwonge herhaling van ' $n$ norm of stel beginsels wat die konvensies van dit waarna verwys word, verberg of veins.

Heteroseksualiteit is hier 'n goeie voorbeeld. In Van Rensburg se stuk word daar baie na homoseksualiteit verwys, en slegs enkele kere na heteroseksualiteit. Die hele betoog kom neer op die handhawing en regverdiging van heteroseksualiteit, sonder dat laasgenoemde as term figureer. Dit word verberg deur te fokus op die teenpool van die begrip waarsonder dit nie kan funksioneer nie, naamlik homoseksualiteit. Deur homoseksualiteit teenoor die monogame huwelik te stel, word die norm van heteronormatiwiteit opgeroep, om deur middel van 'n diskoers (taal) die seksuele verskille tussen mans en vroue te begrond en te orden binne 'n gemeenskap waar mans en vroue bepaalde sosiale rolle het.

Die permanente, een-tot-een-vertrouensverhouding tussen man en vrou as God se wil, stel 'n wetmatigheid daar. As wetmatigheid word dit by herhalende verwysing 'n regulerende instrument wat aan die manlike en vroulike liggame onderskeidelik voortdurende stoflike betekenis gee. Butler (1993:96) praat van "sexed positions". Manlikheid en vroulikheid neem elk 'n seksuele plek en taak aan wat van mekaar verskil, en mekaar uitsluit as dit by dieselfde geslag kom. Heteroseksualiteit repudieer homoseksualiteit en kan net geld as laasgenoemde nie geld nie.

Die veronderstelling van 'n bepaalde soort seksualiteit na aanleiding van geslagsorgane word afgedwing deur heteroseksualiteit as regulerende instrument. Dit is 'n meganisme wat homself herhaal, manlikheid en vroulikheid eerder die gevolg van sonde is! 
deur seksualiteit voordurend te produseer deur middel van 'n stel optredes, wat die dwang van die norm meebring. Anders gestel: mense is nie bloot net mans en vroue nie. Hulle word voortdurend mans en vroue, omdat die norme wat daardie soort liggaamlikheid daarstel, voortdurend uitgespreek word in taal (verwysings, aanhalings). Deur dit voortdurend te noem, word die norm as werklikheid aanvaar, sodat die werklikheid sosiaal daarvolgens ingeklee word. Waar dit nie die werklikheid is nie, word dit voorgegee. Vandaar die oproepe vanuit sommige gaygroeperings om deel te wees van die heteroseksuele orde deur huwelike te mag sluit wat deur die staat erken word en in kerke as bedienaars van die Woord bevestig te mag word.

Waar kom daardie norme vandaan? Dit begin by my geboorte, toe ek as seun benoem is omdat my geslagsdele 'n sekere vorm gehad het. Was daardie geslagsdele onduidelik, sou ek nie kon funksioneer in 'n samelewing wat net rolle het vir mans of vroue nie. Wanneer seksualiteit egter gereduseer word tot biologiese verskille, word geïmpliseer dat prokreasie die mees geskikte norm is om oor geslagtelikheid te dink. Ek is ' $\mathrm{n}$ man, omdat ek die instrument het om kinders by 'n vrou te verwek.

Maar ek is nie 'n man met bepaalde essensies wat my manlikheid bepaal nie. Ek is 'n man wat die merk van manlikheid kry wanneer ek met sekere norme te doen kry en daardie norme voortdurend aangehaal word om 'n bepaalde sosiale orde te skep waarbinne ek moet funksioneer, ten einde die rol van man wat die gemeenskap geformuleer het, te speel. In die Ou Testament het mans hulle manlikheid gevestig deur te domineer. Dominering het geskied deur sekere optredes, soos die seksuele wat op sy beurt, penetrering vereis het. Penetrasie was iets wat die gedomineerde ervaar het, en derhalwe binne 'n skema van eer en skande deur mans vermy moes word (vgl. Stiebert \& Walsh, 2001). In 'n gemeenskap waar manlike oorheersing al hoe meer bevraagteken word, is dit seker logies dat daardie norme wat sodanige oorheersing perpetueer, onder die loep sal kom.

Vandaar die opkoms van queerkritiek. ${ }^{26}$ Queerkritiek probeer om 'n polities-kritiese studie te maak van normatiwiteit en afwykende

26 Queerkritiek onts(e)tel. Schippert (1999:55) sê byvoorbeeld: "Practices which may disturb, trouble - and ultimately shift - some of the relations that make up dominant configurations of normativity." Vir sommige mense beteken dit dat queerkritiek vanuit die staanspoor teen enige norm is: 'n weiering om straight te speel (vgl. Isherwood, 2001:252). Vir ander mense gaan dit egter wyer, naamlik 
kategorieë, veral op die vlak van seksuele aktiwiteite en identiteite. Dit steun sterk op die gedagte dat geslagtelikheid gekonstrueer word binne die samelewing met behulp van diskoers en waarneming.

Geslagtelikheid is nie bloot iets wat essensieël tot 'n mens se identiteit behoort nie, maar iets wat voortdurend gekonstrueer word op grond van sekere norme in die samelewing. Met ander woorde, 'n man of ' $n$ vrou is nie 'n man of ' $n$ vrou op grond van hulle anatomie nie, maar omdat die gemeenskap aan hulle sekere rolle toedig. Die toedigting geskied egter nie sonder norme nie. Binne die gereformeerde gemeenskap is dit die manier hoe dié norme ontgin word in terme van tydgebondenheid of tydgerigtheid, wat problematies geword het.

\section{Konklusie}

Binne 'n omgewing waar 'n leser se subjektiwiteit in terme van common sense verander het, is dit noodwendig dat sekere Bybeltekste in 'n ander lig gelees sal word. Die aandrang op gelykberegtiging in die grondwet het onteenseglik deel van die hermeneutiese raamwerk geword. As man word ek voortdurend gekonfronteer met die feit van manlike oorheersing. Met ander woorde, om 'n gelyke en meer regverdige bedeling vir almal te bewerkstellig, word ek gedwing om vrae te vra ten opsigte van strukture wat manlike oorheersing afdwing, oftewel fallogosentrisme.

Laasgenoemde is in meerdere mate by Augustinus teenwoordig, deurdat hy vroue as minderwaardig en onderdanig sien. In die geskiedenis het dit tot 'n ongelyke magsverhouding gelei wat nie opgelos is deur 'n veranderde plek en betekenis van seksualiteit (die genotsbeginsel) in die huwelik nie. Dit was steeds die genot van die man wat in die visier was. Die veranderde sosiale rol van die vrou het ' $n$ verandering in dié opsig meegebring, sodat biologiese voorkoms al hoe minder die erotiese bestemming bepaal het. Anatomiese komplimentariteit vir prokreasie het selfs oorbodig geword.

die bevraagtekening (query) van sisteme wat mense onderdruk (West, 1999:31). Queerkritiek het weliswaar ontwikkel vanuit gay en lesbiese geledere, maar dit gaan verder, deurdat dit identiteite sien as "multiple, hybrid, provisional or composite in which an infinite number of identity markers can combine to form new sites of knowledge" (Goss, 1999:45). Dit hou verband met die postkoloniale hibriede identiteit, wat die normatiewe kategorieë van die moderne en postmoderne Eerste Wêreld wil ondermyn. 
Skielik begin dié tekste wat aangewend word om homoseksualiteit af te wys, vanuit 'n veranderde hermeneutiese raamwerk ander dinge sê, omdat die vrae wat gevra word, verskil. Dit wat as tydgerig beskou is, is skielik tydgebonde. Is dit bloot eksegetiese willekeur? Ek dink nie so nie.

Eerstens word die nuwe hermeneutiese raamwerk doelbewus verdiskonteer, maar die moontlikheid bestaan wel dat dit op 'n stadium, soos by heteropatriargie, onbewustelik sal begin funksioneer. Dit sal gebeur wanneer dit volledig deel geword het van die nuwe common sense, sodat dit bloot as "natuurlike oordeel" beskou sal word om gelykheid na te streef.

Tweedens word die teks self ondervra in terme van geslagtelikheid. Só 'n vraag noop die eksegeet om die teks binne 'n bepaalde sosiohistoriese konteks te plaas, sodat hy/sy vanuit sy/haar eie sosiohistoriese konteks 'n vergelyking kan maak. Vir 'n gereformeerde wat erns wil maak met die Bybelteks, maar ook as goeie landsburger die grondwet as hermeneutiese raamwerk aanvaar het, sê die Bybel nie meer altyd wat dit in die verlede gesê het nie.

Dié raamwerk lê daardie tekste wat homoseksualiteit afwys se onderliggende regverdiging van manlike oorheersing bloot. Gevolglik word die tekste se verwysing na seksuele omgang tussen lede van dieselfde geslag binne 'n bepaalde ideologiese raamwerk gegiet, wat in 'n ideologie van gelykberegtiging problematies geword het. Om hierdie rede word die verwysings na seksuele omgang tussen lede van dieselfde geslag as tydgebonde gesien, terwyl die tydgerigtheid van die teks verskuif na die wyse hoe 'n man sy rol binne 'n gemeenskap konstrueer. Waar die man in die antieke tyd daardie rol kon formuleer in terme van manlike oorheersing, moet dit nou geskied in terme van gelyke beregtiging. Die netwerk van betekenisse en norme waarbinne die tekste eens op 'n tyd gefunksioneer het, het verdwyn, sodat die eksegeet 'n ander strukturele resonans met die tekste moet vind ten einde hulle te laat meespreek in sy/haar situasie. Dit beteken dat die tekste 'n ander rol speel as waarvoor hulle op ' $n$ tyd aangewend is.

Die onderskeid tussen man en vrou wat berus op anatomiese voorkoms as skeppingsbeginsel, word deur die verskynsel van interseksualiteit geproblematiseer. Anatomiese voorkoms is 'n belangrike argument in die afwysing van homoseksualiteit, terwyl interseksualiteit anatomiese voorkoms as paradigma bevraagteken. Boonop is daar 'n Joodse tradisie wat die radikale onderskeid tussen man en vrou bevraagteken en die mens androgenies maak. 
Die kategorieë manlik/vroulik of homoseksueel/heteroseksueel maak nie sin vir 'n interseksuele persoon nie.

Anatomiese voorkoms as skeppingsbeginsel maak die deur oop vir 'n essensialistiese beskouing oor wat ' $n$ man of ' $n$ vrou is. Die menslike geslagsdele bepaal optrede, karakter en uiteindelik mag. Die rolle wat aan 'n man en 'n vrou toegedig word, is gegrond op norme wat op essensies berus. Dit het 'n wetenskaplike positivisme tot gevolg, waarvolgens die teks bloot as bewysstuk gehanteer word, sonder inagneming van enige subjektiwiteit. Só 'n lees gee nie genoegsaam aandag aan die sosiale ligging van die leser van die teks nie, en dit neem nie die politieke konteks waarbinne die teks verstaan of geproduseer word, voldoende in ag nie.27

Is dit wat ons in die Bybel sien as tydgerig, 'n altydgeldende beginsel, nie reeds vooraf gerig deur 'n bepaalde subjektiwiteit nie? In my beoordeling van die opwerp van altydgeldende beginsels wat uit die Bybel afgelei word, kan ek nie "die bedreiging van die willekeur van die eksegeet" ontkom nie. Dit hang soos 'n swaard oor 'n Bybelleser se kop, gereed om enige argument wat die normatiewe uitdaag, kort te knip. Die debat oor seksualiteit (homo/hetero/inter) kan nie gevoer word sonder dat die subjektiewe, die willekeur, 'n rol speel nie. Die subjektiewe kan egter ingeperk word deur nie net te erken dat dit 'n rol speel nie, maar inderdaad te kyk in watter opsigte dit interpretasie beïnvloed.

Miskien sou iemand kon aanvaar dat 'n Bybelleser sy/haar posisie vanuit die Bybel laat bepaal. Maar dit is juis die probleem: vóór die teks enigsins gebruik kan word, is daar reeds 'n perspektief waarmee die teks benader word. Dit is daardie perspektief wat bespreek moet word. Dit is nie iets wat in die Bybel is nie, maar ' $n$ norm wat buite geld en ingelees word en dan uitgehaal word asof dit in die Bybel staan.

\section{Geraadpleegde bronne}

AUGUSTINUS. 1988. On the good of marriage [De bono conjugali]. Vert. C.L. Cornish. (In Schaff, P., ed. A select library of the Nicene and post-Nicene fathers of the Christian church. Edinburgh: Clark. p. 395-413.)

27 Ek vermoed dat dit wat ek as genoegsaam en voldoende beskou, binne die tradisionele gereformeerde hermeneutiek as oormatig beskou sal word. Vergelyk Snyman (2003) se kritiek op die aanwending van sosio-historiese gegewens in die interpretasieproses. As feilbare instrument mag dit nie hoër as die Bybelteks self geag word nie. 
BOISVERT, D.L. 1999. Queering the sacred: discourses of gay male spiritual writing. Theology and Sexuality, 10:54-70.

BOSHOFF, W.S. 2000. God's wife? The inscriptions from Kuntillet 'Ajrud. (In Scheffler, E., ed. Fascinating discoveries from the biblical world. Pretoria: Biblia. p. 100-106.)

BOTHA, P.H. s.a. The Apostle Paul and homosexuality: a socio-historical study. Potchefstroom: Noordwes-Universiteit. (Ongepubliseerde proefskrif.)

BREED, D. 2006. Kwade dag as GKSA Christina volg. Beeld: 14, 26 Jan.

BROOTEN, B.J. 2003. Nature, law, and custom in Augustine's On the good of marriage. (In Matthews, S., Briggs Kittredge, C. \& Johnson-Debaufre, M., eds. Walk in the ways of wisdom: essays in honor of Elisabeth SchüsslerFiorenza. New York: Trinity. p. 181-193.)

BUTLER, J. 1993. Bodies that matter: on the discursive limits of "sex". London: Routledge.

COETZEE, J.C., DE KLERK, B.J. \& FLOOR, L. 1980. Die hermeneuse van die Skrif met die oog op hedendaagse kerklik-etiese vraagstukke. In die Skriflig, 14(4):12-26.

COTHEY, A. 2005. Ethics and holiness in the theology of Leviticus. Journal for the Study of the Old Testament, 30(2):131-151.

CROMPTON, L. 2003. Homosexuality \& civilization. Cambridge: The Belknap Press of Harvard University Press.

DAVIES, M. 1995. New Testament ethics and ours: homosexuality and sexuality in Romans 1:26-27. Biblical Interpretation, 3(3):315-31.

DREGER, A.D. 1998. "Ambigious sex" - or ambivalent medicine? Ethical issues in the treatment of intersexuality. Hastings Center Report, 28:24-36.

EILBERG-SCHWARZ, H. 1994. God's phallus and other problems for men and monotheism. Boston: Beacon.

ELLIOT, C. 1998. Why can't we go on as three? Hastings Center Report, 28:3639.

ELS, J. 2005. 'n Pa se pyn. Sarie: 50-51, Jun.

GOSS, R. 1999. Queer theologies as transgressive metaphors: new paradigms for hybrid sexual theologies. Theology and Sexuality, 10:43-53.

GREIJDANUS, S. 1946. Schriftbeginselen ter Schriftverklaring en historisch oversicht over theorieën en wijzen van Schriftuitleggen. Kampen: Kok.

GROSS, S. 1999. Intersexuality and Scripture. Theology and Sexuality, 11:6574.

HELBERG, J.L. 1983. Die Here regeer: openbaringslyn deur die Ou Testament. Pretoria: NG Kerk Boekhandel.

HESTER, J.D. s.a. Rhetoric of the medical management of intersexed children. Queen, a journal of rhetoric and power. (Special issue: The rhetoric of healing.) http://www.ars-rhetorica.net/Queen/VolumeSpeciallssue/Articles/ Hester.html Date of access: 5 Jul. 2005.

HOROWITZ, M.C. 1979. The image of God in man - is woman included? Harvard Theological Review, 72 (3/4):175-206.

HUMAN, D. 2005. Homoseksualiteit - perspektiewe in die antieke Nabye Ooste. Old Testament Essays, 18(3):629-636.

HUNT, M. E. 2001. Queering old time religion. Literature \& Theology, 15(3):21023.

ISHERWOOD, L. 2001. Queering Christ: outrageous acts and theological rebellions. Literature \& Theology, 15(3):249-61.

KATZ, J.N. 1995. The invention of heterosexuality. New York: Dutton. 
LOOY, H. 2002. Male and female God created them: the challenge of intersexuality. Journal of Psychology and Christianity, 21(1):10-20.

MARTIN, D. 1995. Heterosexism and the interpretation of Romans 1:18-32. Biblical Interpretation, 3(3):332-35.

MOHRMANN, D.C. 2004. Making sense of sex: a study of Leviticus 18. Journal for the Study of the Old Testament, 29(1):57-79.

RAMSHAW, E.J. 2003. Sexuality is (a) deeply problematic (b) God's gift (c) a hoot. Currents in Theology and Mission, 30(1):20-29.

SCHIPPERT, C. 1999. Too much trouble? Negotiating feminist and queer approaches in religion. Theology and Sexuality, 10:44-63.

SCHÜSSLER-FIORENZA, E. 1988. The ethics of biblical interpretation: decentering biblical scholarship. Journal of Biblical Literature, 107:3-17.

SMIT, C.J. \& VORSTER, J.M. 2000. Die GKSA en sy gereformeerde identiteit: kan dit behou word in 'n postmoderne gemeenskap? In die Skriflig, 34(4):515-533.

SMITH, A. 1999. "Straight problems": the sacralization of homophobia, women's sexuality, lesbian invisibility and the British church. Theology and Sexuality, 10:88-102.

SNYMAN, G.F. 2002. Telling women to be like men? Some theoretical aspects regarding the interpretation of the Bible on gender issues. Koers, 67(1):126.

SNYMAN, S.D. et al., sameroeper. 2003. Rapport van die Deputate Leerstellige Sake: vroue in die kerk (Artt. 43.1, 235). http://www.gksa. org.za/sinode2003/leerstellig/vrou\%20in\%20kerk\%201.htm Datum van toegang: 23 Jun. 2005.

STIEBERT, J. \& WALSH, J.T. 2001. Does the Bible have anything to say about homosexuality? OTE, 14(1):119-152.

VAN NIEKERK, P. 2006. Skrik wakker, broeders: diskriminasie teen vroue plaas kerk se geloofwaardigheid op die spel. Beeld: 11, 18 Jan.

VAN RENSBURG, F. 2005. Hoe gedink oor homoseksuele verhoudings? Die Kerkblad: 10-11, Jan.

VAN ROOY, H.F. 2001. Per bonam consequentiam: die status van eksegetiese afleidings. In die Skriflig, 35(1):45-59.

VAN WYK, J.H. 2002. Venialis culpa? Augustinus oor huwelik en seksualiteit. In die Skriflig, 36(3):327-348.

VERGEER, W.C. \& JANSE VAN RENSBURG, J.J. 2003. Beswaarskrif W.C. Vergeer en J.J. Janse van Rensburg teen besluite van die Sinode 1988: die vrou in die besondere ampte (Artt. 8, 43.4, 234). http://www.gksa.org.za/sinode2003/leerstellig/vergeer\%20vida.htm Datum van toegang: 23 Jun. 2005.

WEST, M. 1999. Reading the Bible as queer Americans: social location and the Hebrew Scriptures. Theology and Sexuality, 10:28-42.

WINK, W. 1994. Walter Wink on homosexuality and the Bible. http://christianity.about.com/library/weekly/blwink.htm Date of access: 29 Jun. 2005. 


\section{Kernbegrippe:}

hermeneutiek

heteroseksualiteit

queerkritiek

retoriek

skepping

Key concepts:

creation

hermeneutics

heterosexuality

queer criticism

rhetoric 